\title{
Manfaat Wisata Tugu Kebulatan Proklamasi Di Rengasdengklok Karawang Bagi Masyarakat Lokal Sebagai Peluang Usaha Untuk Meningkatkan Taraf Hidup Sebagai Pedagang Kecil.
}

\author{
Rieke Retnosary \\ Fakultas Teknologi Informatika dan Komputer \\ Universitas Buana Perjuangan Karawang \\ rieke.retnosary@ubpkarawang.ac.id
}

\begin{abstract}
Abstrak
Tugu Kebulatan Proklamasi (TKP) as a destination of heritage tourism in Rengasdengklok, Karawang, has given opportunity to many local residents to increasing their income for better family economic.

Researcher found in observed that characteristic of small business from TKP area was on food bussiness and cloths. In holiday time, many small traders (pedagang kecil) for the local visitor or tourism was offered besides food, small traders such as toys for children and other specification of children's game.

But for this research, researcher just focus on local or ordinary foods.

Small traders offering the local food and ordinary food, like gorengan, mie ayam, bakso, es kelapa, and serabi, ordinary drink like, coffee and other thing that they can offer. Some time they (as a small traders) offer the mie ayam and provided the drink too, such as tea or mineral water and so on.

Five (5) small traders which interviewed feel the positive impact from the existences of TKP. From five (5) small traders, their income were between Rp 3,000,000 until 9,000,000 per month, the average of their income was Rp 5,800,000. This income very convenience for local residents if they want to take food for business.

According to the mandate of article (pasal) 31 paragraph (ayat) (4) number of law 10 in 2009 about the tourism, that the aim of tourism is to increase economic growth and people welfare. With tourism, people or local resident could increase with many opportunity for small economic problems.
\end{abstract}

56.

Jurnal Manajemen \& Bisnis Kreatif 
Key words: TKP Tourism, opportunity, local residents, increase income, positive impact, small traders, economic growth.

\section{PENDAHULUAN}

Pengembangan sektor pariwisata di Karawang sebagai suatu kegiatan ekonomi masyarakat daerah harus dilakukan agar terjadi peningkatan pendapatan masyarakat dan daerah. Pendapatan Asli Daerah (PAD) Kabupaten Karawang hanya naik 2\% tahun 2016 (tahun 2015 sebesar Rp 930 miliar menjadi Rp 946 miliar) dalam Anggaran Pendapatan dan Belanja Daerah (APBD) menurut wakil ketua DPRD Sri Rahayu Agustin dalam pernyataannya di Pikiran Rakyat Minggu (14/2/2016). Pernyataan Sri Rahayu, bahwa salahsatu sektor pendongkrak perekonomian adalah dari pariwisata yang sayangnya belum ditanggapi serius oleh pihak eksekutif daerah, sehingga pariwisata yang dimiliki Karawang belum dapat diolah sedemikian rupa untuk menarik wisatawan berkunjung.

Undang-undang No. 10 Tahun 2009 pasal 5 tentang kepariwisataan diselenggarakan dengan prinsip : a. menjunjung tinggi norma agama dan nilai budaya sebagai pengejawantahan dari konsep hidup dalam keseimbangan hubungan antara manusia dan Tuhan Yang Maha Esa, hubungan antara manusia dan sesama manusia, dan hubungan antara manusia dan lingkungan; b. menjunjung tinggi hak asasi manusia, kergaman budaya, dan kearifan lokal; c. memberi manfaat untuk kesejahteraan rakyat, keadilan, kesetaraan, dan proporsionalitas.

Pasal 31 ayat (4) Undang-undang No. 10 Tahun 2009 tentang kepariwisataan bahwa, pariwisata bertujuan untuk meningkatkan pertumbuhan ekonomi dan kesejahteraan rakyat.

Inilah yang menjadi landasan bagi pemerintah daerah Karawang mengolah sektor pariwisata menjadi asset daerah yang menjanjikan.

Pariwisata tidak hanya merupakan kegiatan rekreasi masyarakat yang membutuhkan hiburan, tetapi juga yang membutuhkan informasi atas sejarah masa lalu untuk dipelajari dan diingat sebagai jatidiri bangsa. Rengasdengklok merupakan salahsatu wisata daerah yang memiliki nilai sejarah tinggi tetapi apresiasi oleh pemerintah daerah belum peneliti pahami terhadap kepentingan masyarakat lokal dalam penggerakan ekonomi. Dilihat dari kegiatan perekonomiannya yang standard dan lingkungan sekitar yang kurang terawat, peneliti berusaha untuk menggali nilai 
manfaat pariwisata bagi masyarakat sehingga penelitian ini diberi judul Manfaat Wisata Tugu Kebulatan Proklamasi Di Rengasdengklok Karawang Bagi Masyarakat Lokal Sebagai Peluang Usaha Untuk Meningkatkan Taraf Hidup Sebagai Pedagang Kecil.

Dihubungkan dengan kajian sebelumnya bahwa pariwisata dapat memberikan penawaran yang variatif dengan makanan, selain tempat dan keontetikan wisata tersebut (Sims, Rebecca. 2009), maka pengunjung wisata diharapkan dapat singgah lebih lama, selain pengalaman dan biasa memberikan kontribusi kepada masyarakat lokal dengan membeli apa yang ditawarkan masyarakat lokal sebagai pedagang kecil.

Tujuan penelitian ini adalah mengidentifikasi dan menganalisis:

1. Sejauh mana manfaat yang dirasakan oleh penduduk lokal sebagai pedagang kecil dari adanya wisata TKP di Rengasdengklok, Karawang.

2. Faktor-faktor yang menjadi kendala dalam menjalankan peluang usaha sebagai pedagang kecil dari adanya wisata TKP di Rengasdengklok, Karawang.

3. Seperti apakah harapan penduduk lokal sebagai pedagang kecil terhadap pemerintah daerah sebagai pemegang kebijakan wisata TKP di Rengasdengklok, Karawang.

\section{LANDASAN TEORI}

\section{Definisi Pariwisata}

Pariwisata didefinisikan sangat beragam, tetapi memiliki inti adalah pariwisata merupakan fenomena dan berhubungan dengan perjalanan dan singgah sementara seseorang untuk menghabiskan waktu luang (leisure) dan atau untuk tujuan rekreasi (recreational purposes). Menghabiskan waktu luang bisa dengan melakukan kegiatan di dalam rumah seperti menonton televisi, pergi ke bioskop atau berjalan-jalan di taman. Dalam pembahasan lain, pariwisata juga bisa dikategorikan paling tidak menginap satu malam di tempat penduduk atau penduduk asli setempat (Pearce, Douglas.1989).

Dalam Undang-undang Republik Indonesia No. 10 Tahun 2009 tentang Kepariwisataan di Ketentuan Umum mendefinisikan wisata adalah kegiatan perjalanan yang dilakukan oleh seseorang atau sekelompok orang dengan mengunjungi tempat tertentu untuk tujuan rekreasi, 
pengembangan pribadi, atau mempelajari keunikan daya Tarik wisata yang dikunjungi dalam jangka waktu sementara.

\section{Regulasi Pariwisata}

Undang-undang No. 10 Tahun 2009 pasal 5 tentang kepariwisataan diselenggarakan dengan prinsip : a. menjunjung tinggi norma agama dan nilai budaya sebagai pengejawantahan dari konsep hidup dalam keseimbangan hubungan antara manusia dan Tuhan Yang Maha Esa, hubungan antara manusia dan sesama manusia, dan hubungan antara manusia dan lingkungan; b. menjunjung tinggi hak asasi manusia, kergaman budaya, dan kearifan lokal; c. memberi manfaat untuk kesejahteraan rakyat, keadilan, kesetaraan, dan proporsionalitas.

Pasal 31 ayat (4) Undang-undang No. 10 Tahun 2009 tentang kepariwisataan bahwa, pariwisata bertujuan untuk meningkatkan pertumbuhan ekonomi dan kesejahteraan rakyat.

\section{Tinjauan Pustaka}

Pariwisata merupakan industri yang cukup menjanjikan bagi suatu negara untuk meningkatkan ekonomi negara dan/atau daerahnya. Seperti menurut Arslanturk, Yalcin at all (2011) menyatakan bahwa hasil analisisnya dari beberapa penelitiannya, penerimaan pariwisata dapat memberikan dampak positif dalan pertumbuhan ekonomi di Turki. Franz Scubert, Stefan at all (2011) menyatakan bahwa dampak pariwisata sangat membantu pertumbuhan ekonomi dimana dari hasil hipotesisnya, tourism as the engine for economic growth (pariwisata sebagai "mesin" untuk pertumbuhan ekonomi). Begitu pula menurut Priono, Yasser (2011), dalam penelitiannya di Bukit Kasongan, Kabupaten Katingan, Kalimantan Tengah bahwa dampak positif ditinjau dari aspek ekonomi dapat meningkatkan pendapatan penduduk lokal, peningkatan pendapatan pemerintah daerah, sarana peningkatan pendidikan konservasi flora yang dilestarikan. Penelitian lain yang dilakukan oleh Sims, Rebecca (2009), melalui makanan dan minuman yang ditawarkan dalam kunjungan tertentu, memberikan peluang lebih untuk menjadi sukses sehingga menjadi kunjungan yang berkesinambungan.

Poudel, Surya at all (2016) dalam penelitiannya mengungkapkan bahwa penduduk dan pengunjung akan merasakan dampak positif dan negatif yang berbeda dalam area wisata yang dilindungi oleh stakeholder pariwisata tersebut jika mengarah pada perspektif pembangunan pariwisata yang berkesinambungan (Sustainable Tourism Development).

59.

Jurnal Manajemen \& Bisnis Kreatif 
Artinya, perlakuan atas tempat wisata yang terjaga dengan baik (manajemen yang baik) akan memberikan dampak yang baik terutama bagi kelangsungan wisata dan kehidupan penduduk lokal itu sendiri, karena baik pengunjung maupun penduduk lokal akan mengikuti aturan yang dibuat oleh pemerintah daerah dan atau penanggungjawab atau stakeholder tersebut.

Dari beberapa tinjauan pustaka (hasil penelitian terdahulu) didapat konsep dasar seperti pada gambar 1.1

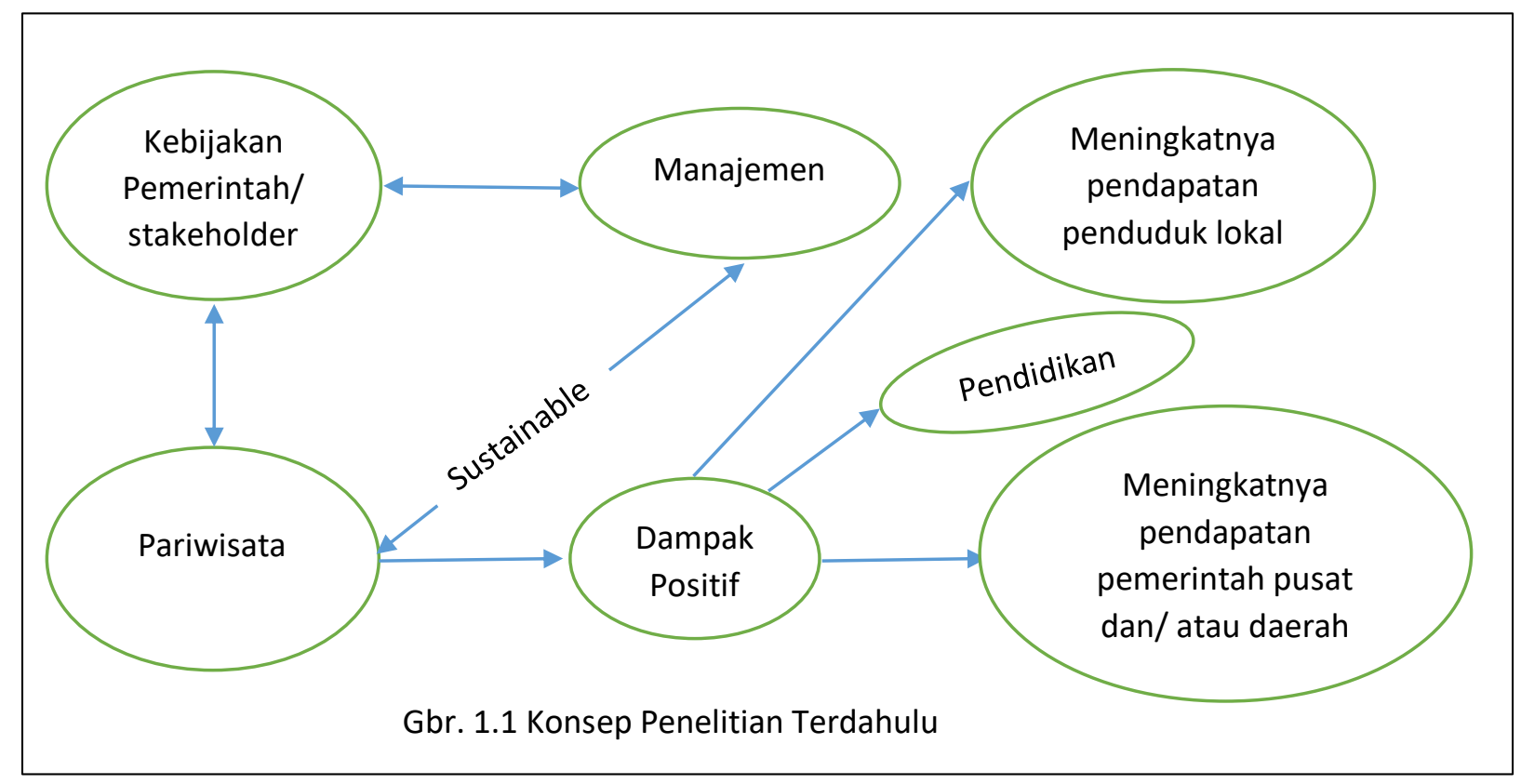

\section{Kategori Usaha dan/atau Pedagang}

\section{Definisi Usaha dalam Undang-Undang Republik Indonesia Nomor 20 Tahun 2008}

Dalam amanat Ketetapan Majelis Permusyawaratan Rakyat Republik Indonesia No. XVI/MPRRI/1998 bagian (d) dalam Undang-undang RI No. 20 tahun 2008 tentang Politik Ekonomi dalam rangka Demokrasi Ekonomi, Usaha Mikro, Kecil, dan Menengah perlu diberdayakan sebagai bagian integral ekonomi rakyat yang mempunyai kedudukan, peran, dan berkeadilan.

Dalam Bab I, Ketentuan Umum pasal 1, Undang-udang tentang Usaha Mikro , Kecil, dan Menengah didefinisikan sebagaiberikut:

1. Usaha Mikro adalah usaha produktif milik orang perorangan dan/atau badan usaha perorangan yang memenuhi kriteria Usaha Mikro sebagaimana diatur dalam UndangUndang ini.

60. 
2. Usaha Kecil adalah usaha ekonomi produktif yang berdiri sendiri, yang dilakukan oleh orang perorangan atau badan usaha yang bukan merupakan anak perusahaan atau bukan cabang perusahaan, yang dimiliki, dikuasai, atau menjadi bagian baik langsung maupun tidak langsung dari Usaha Menengah atau Usaha Besar yang memenuhi kriteria Usaha Kecil sebagaimana dimaksud dalam Undang-Undang ini.

3. Usaha Menengah adalah usaha ekonomi produktif yang berdiri sendiri, yang dilakukan oleh orang, perorangan atau badan usaha yang bukan merupakan anak perusahaan atau cabang perusahaan yang dimiliki, dikuasai, atau menjadi bagian baik langsung maupun tidak langsung dengan Usaha Kecil atau Usaha Besar dengan jumlah kekayaan bersih atau hasil penjualan tahunan sebagaimana diatur dalam Undang-Undang ini

4. Usaha besar adalah usaha ekonomi produktif yang dilakukan oleh badan usaha dengan jumlah kekayaan bersih atau hasil penjualan tahunan lebih besar dari Usaha Menengah, yaitu meliputi usaha nasional milik negaraa atau swasta, usaha patungan, dan usaha asing yang melakukan kegiatan ekonomi di Indonesia.

Bab II, Asas dan Tujuan pasal 3, Usaha Mikro, Kecil, dan Menengah bertujuan menumbuhkan dan mengembangkan usahanya dalam rangka membangun perekonomian nasional berdasarkan demokrasi ekonomi yang berkeadilan.

Bab IV, Pasal 6 menjelaskan kriteria-kriteria Usaha, yaitu:

(1) Kriteria Usaha Mikro adalah sebagai berikut:

a. memiliki kekayaan bersih paling banyak Rp 50.000.000,00 (lima puluh juta rupiah) tidak termasuk tanah dan bangunan tempat usaha; atau

b. memiliki hasil penjualan tahunan paling banyak Rp 300.000.000,00 (tiga ratus juta rupiah).

(2) Kriteria Usaha Kecil adalah sebagai berikut:

a. memiliki kekayaan bersih lebih dari Rp 50.000.000,00 (lima puluh juta rupiah) sampai dengan paling banyak Rp 500.000.000,00 9lima ratus juta rupiah) tidak termasuk tanah dan bangunan tempat usaha; atau

b. memiliki hasil penjualan tahunan lebih dari Rp 300.000.000,00 (tiga ratus juta rupiah) sampai dengan paling banyak Rp 2.500.000.000,00 (dua milyar limaratus juta rupiah).

61. 
(3) Kriteria Usaha Menengah adalah sebagai berikut:

a. memiliki kekayaan bersih lebih dari Rp 500.000.000,00 (lima ratur juta rupiah) sampai dengan paling banyak Rp 10.000.000,00 (sepuluh milyar rupiah) tidak termasuk tanah dan bangunan tempat usaha; atau

b. memiliki hasil penjualan tahunan lebih dari Rp 2.500.000.000,00 (dua milyar limaratus juta rupiah) sampai dengan paling banyak Rp 50.000.000.000,00 (lima puluh milyar rupiah)

(4) Kriteria sebagaimana dimaksud pada ayat (1) huruf a, huruf b, dan ayat (2) huruf a, huruf b, serta ayat (3) huruf a, huruf b nilai nominalnya dapat diubah sesuai dengan perkembangan perekonomian yang diatur dengan Peraturan Presiden.

\section{Definisi Pedagang dalam Peraturan Menteri Dalam Negeri Republik Indonesia Nomor 41 Tahun 2012, tentang Pedoman Penataan Dan Pemberdayaan Pedagang Kaki Lima}

Kaki Lima dalam Bab 1 Pasal 1 di Ketentuan Umum, dalam peraturan Menteri ini yang dimaksud dengan:

1. Pedagang Kaki Lima, yang selanjutnya disingkat PKL, adalah pelaku usaha yang melakukan usaha perdagangan dengan menggunakan sarana usaha bergerak maupun tidak bergerak, menggunakan prasarana kota, fasilitas sosial, fasilitas umum, lahan dan bangunan milik pemerintah dan/atau swasta yang bersifat sementar/tidak menetap.

2. Penataan PKL adalah upaya yang dilakukan oleh pemerintah daerah melalui penetapan lokasi binaan untuk melakukan penetapan, pemindahan, penertiban dan penghapusan lokasi PKL dengan memperhatikan kepentingan umum, sosial, estetika, kesehatan, ekonomi, keamanan, ketertiban, kebersihan lingkungan dan sesuai dengan peraturan perundang-undangan.

3. Pemberdayaan PKL adalah upaya yang dilakukan oleh pemerintah, pemerintah daerah, dunia usaha dan masyarakat secara sinergis dalam bentuk penumbuhan iklim usaha dan pengembangan usaha terhadap PKL sehingga mampu tumbuh dan berkembang baik kualitas maupun kuantitas usahanya.

4. Lokasi PKL adalah tempat untuk menjalankan usaha PKL yang berada di lahan dan/atau bangunan milik pemerintah daerah dan/atau swasta. 
5. Lokasi binaan adalah lokasi yang telah ditetapkan peruntukannya bagi PKL yang diatur oleh pemerintah daerah, baik bersifat permanen maupun sementara.

6. Tanda Daftar Usaha, yang selanjutnya disebut TDU, adalah surat yang dikeluarkan oleh pejabat yang ditunjuk sebagai tanda bukti pendaftaran usaha PKL sekaligus sebagai alat kendali untuk pemberdayaan dan pengembangan usaha PKL di lokasi yang ditetapkan oleh pemerintah daerah.

7. Rencana Pembangunan Jangka Menengah Daerah, yang selanjutnya disingkat RPJMD, adalah dokumen perencanaan daerah untuk periode 5 (lima) tahun.

8. Satuan Kerja Pemerintah Daerah, yang selanjutnya disingkat SKPD, adalah perangkat daerah sebagai unsur penyelenggara pemerintah daerah.

9. Pemerintah Daerah adalah Gubernur, Bupati, atau Walikota dan perangkat daerah sebagai unsur penyelenggara pemerintah daerah

10. Rencana Strategis SKPD, yang selanjutnya disebut dengan Renstra SKPD, adalah dokumen perencanaan SKPD untuk periode 5 (lima) tahun.

11. Menteri adalah Menteri Dalam Negeri.

\section{Konsep Dasar Penelitian}

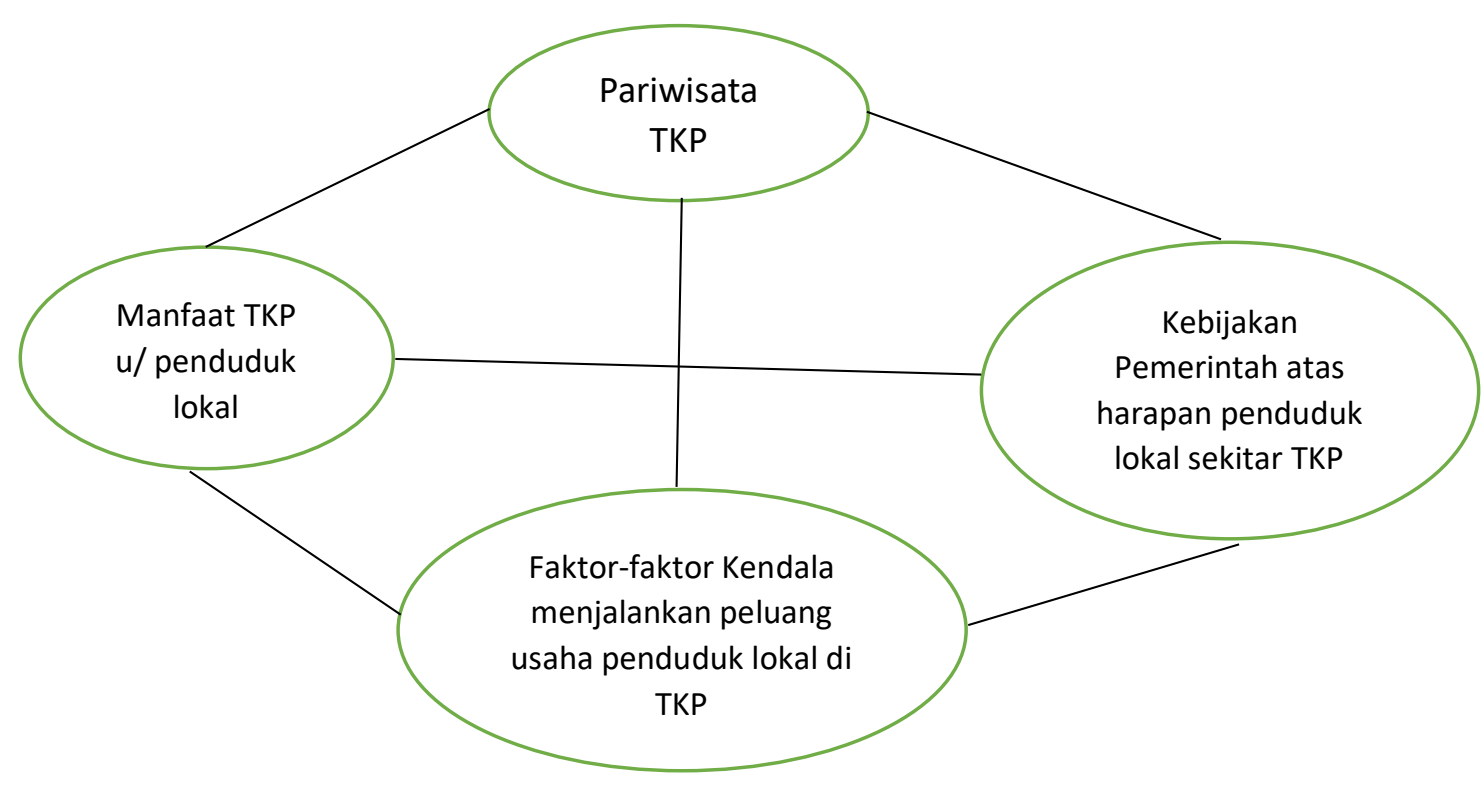

Gbr. 1.2 Konsep Dasar Penelitian

63. 


\section{METODE PENELITIAN}

Metode penelitian yang digunakan adalah Kualitatif, desain penelitian adalah exploratory, koleksi data dengan melakukan observasi dan wawancara (interview), termasuk dokumentasi (foto dan buku tamu)

Observasi dilakukan disekitar area rengas dengklok, situs TKP, dan pedagang.

Wawancara dilakukan hanya kepada 5 responden yaitu penduduk lokal yang berjualan (sebagai pedagang kecil) disekitar area rengas dengklok dan penanggung jawab atas situs TKP (juru kunci).

J. Maleong, Lexy (2014) menyatakan bahwa, biasanya data dianalisis secara deskriptif yang sebagian besar berasal dari wawancara dan catatan pengamatan; catatan dianalisis untuk memperoleh tema dan pola-pola yang dideskripsikan dan diilustrasikan dengan contoh-contoh, termasuk kutipan-kutipan dan rangkuman dari dokumen; koding data dan analisis verbal.

Miles \& Huberman (1984) dalam Sugiyono (2012), mengemukakan bahwa aktivitas dalam analisis data kualitatif dilakukan secara interaktif dan berlangsung secara terus menerus sampai tuntas, hingga data jenuh. Komponen analisis data diterjemahkan dalam alur :

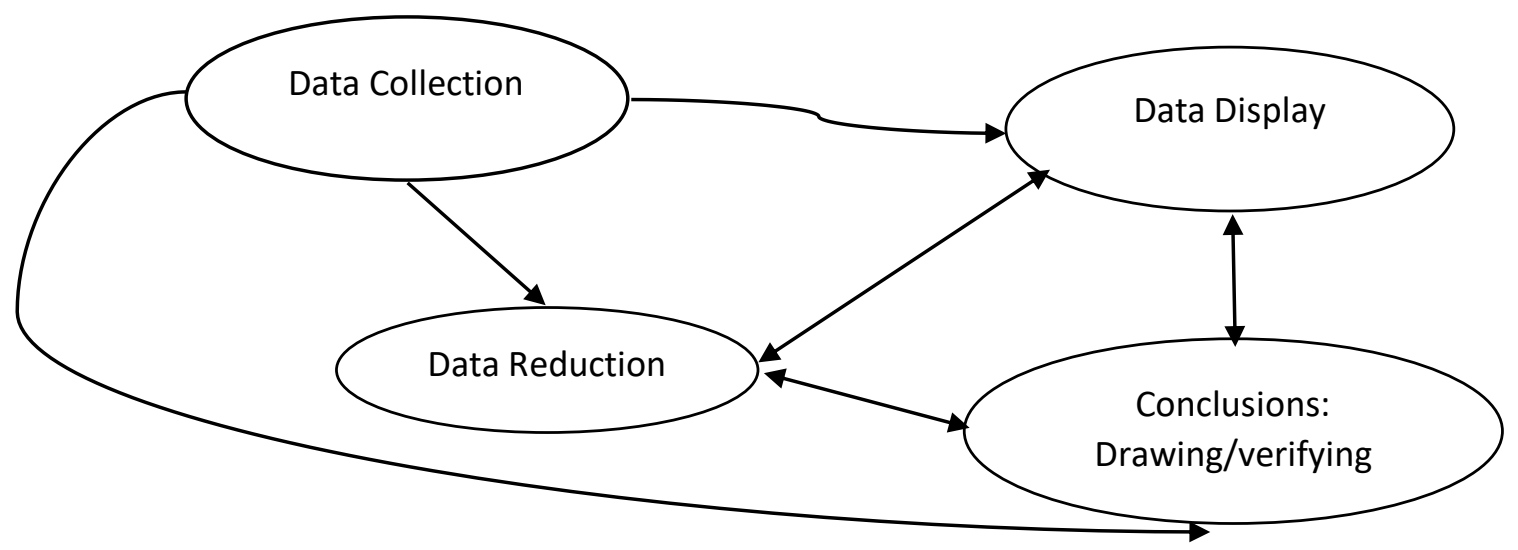

Gbr. 1.3 Model komponen dalam analisis data

(sumber: Sugiyono.2012: 247) 
PROSEDUR PENELITIAN

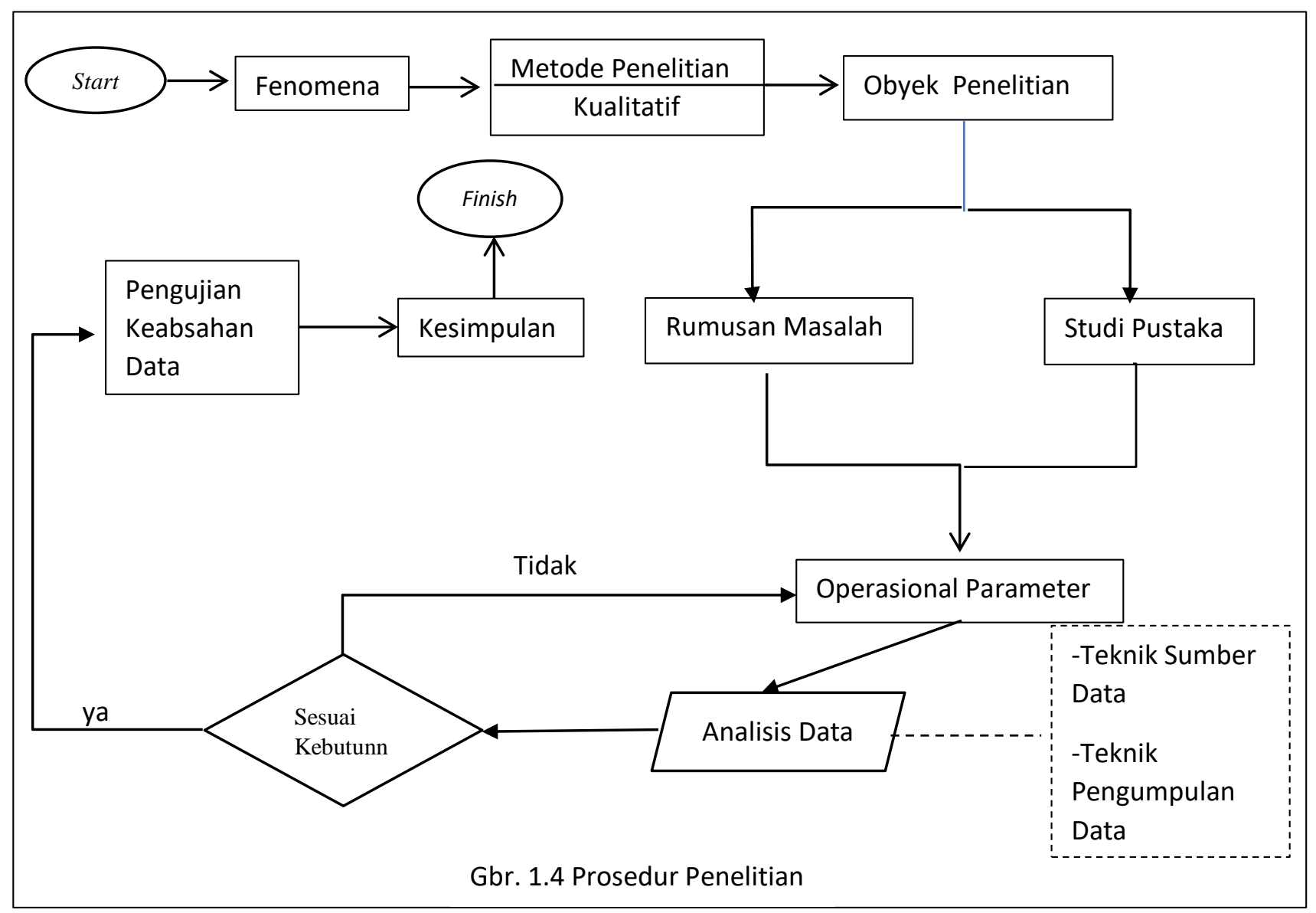

\section{HASIL PENELITIAN DAN PEMBAHASAN}

\section{Gambaran Umum lokasi Penelitian}

Tugu Kebulatan Proklamasi (TKP) yang dikenal sebagai Monumen Kebulatan Tekad dibangun pada tahun 1950, setelah 5 tahun merdeka (17 Agustus 1945).

TKP, terletak di Kecamatan Rengasdengklok 20 km dari Ibu Kota Kabupaten Karawang.Di tempat ini pernah terjadi peristiwa sejarah yang menentukan kemerdekaan Indonesia. TKP terletak di Jalan Raya Rengasdengklok, Karawang.

Menurut penjaga TKP (juru kunci) yaitu bapak Idris, bahwa pada saat sebelum kemerdekaan para pemuda menculik Soekarno untuk mendesak golongan tua segera memproklamasikan kemerdekaan.

65. 


\section{Hasil Penelitian}

Dari hasil observasi, kategori usaha yang dilakukan oleh penduduk lokal sebagai pedagang tidak mendekati kategori Usaha Mikro sesuai definisi Usaha dan Kriteria-kriteria Usaha dalam UndangUndang Republik Indonesia Nomor 20 Tahun 2008, melainkan masuk pada kategori Pedagang Kaki Lima (PKL) di poin 1 definisi Pedagang dalam Peraturan Menteri Dalam Negeri Republik Indonesia Nomor 41 Tahun 2012, tentang Pedoman Penataan Dan Pemberdayaan Pedagang Kaki Lima dimana dalam Bab 1 Pasal 1 di Ketentuan Umum, dalam peraturan Menteri ini yang dimaksud dengan:

Pedagang Kaki Lima, yang selanjutnya disingkat PKL, adalah pelaku usaha yang melakukan usaha perdagangan dengan menggunakan sarana usaha bergerak maupun tidak bergerak, menggunakan prasarana kota, fasilitas sosial, fasilitas umum, lahan dan bangunan milik pemerintah dan/atau swasta yang bersifat sementar/tidak menetap. (untuk 3 (tiga) pedagang: mie ayam, es kelapa, gorengan termasuk beberapa pedagang lain yang tidak diwawancara oleh peneliti)

Sedangkan untuk warung kopi dan pedagang serabi, menggunakan lahan dirumahnya sendiri.

Penelitian dilakukan dengan wawancara kepada penduduk lokal yang mengambil peluang berdagang di sekitar TKP. Jumlah responden sebanyak 5 orang yang memang tidak mempunyai pekerjaan lain selain berdagang makanan dan minuman di daerah tersebut, adapun ditemukannya pedagang baju yang menetap tidak dilakukan wawancara karena tidak berkenan untuk diwawancarai.

Tabel 1.1 Data Pedagang

\begin{tabular}{|l|l|l|l|l|l|}
\hline No. & Nama Pedagang & $\begin{array}{c}\text { Usia, } \\
\text { Thn }\end{array}$ & $\begin{array}{l}\text { Jumlah Keluarga, } \\
\text { orang }\end{array}$ & $\begin{array}{c}\text { Jenis Barang } \\
\text { Dagangan }\end{array}$ & $\begin{array}{c}\text { Pendapatan } \\
\text { rata-rata, Rp }\end{array}$ \\
\hline 1. & Santo & - & 4 & Bakso & $5.000 .000 / \mathrm{bl}$ \\
\hline 2. & M. Asim & 61 & 3 & Serabi & $6.000 .000 / \mathrm{bl}$ \\
\hline 3. & Ica & 55 & 3 & Es Kelapa & $3.000 .000 / \mathrm{bl}$ \\
\hline 4. & Kris Rohadi & 29 & 2 & Gorengan & $9.000 .000 / \mathrm{bl}$ \\
\hline 5. & Enen & 52 & 4 & Warung Kopi & $6.000 .000 / \mathrm{bl}$ \\
\hline
\end{tabular}

Menurut para pedagang dengan adanya TKP sebagai tempat wisata atau kunjungan sejarah, ekonomi keluarga mereka cukup terbantu. Dengan adanya wisata ini, desa selalu ramai dengan 
pengunjung/ wisatawan yang kemudian mampir di tempat usaha mereka. Namun dalam hasil wawancara juga, ada harapan bagi para pedagang untuk mendapatkan perhatian pemerintah daerah. Baik itu perbaikan sarana sekitar wisata maupun perhatian pada perekonomian para pedagang dan penduduk lokal untuk meningkatkan ekonomi mereka terutama modal dagang, agar yang mereka tawarkan kepada pengunjung lebih bervariasi/ banyak pilihan.

Pada kegiatan observasi, peneliti menemukan ketidak teraturan pengelolaan lingkungan sekitar yang berhubungan dengan kebersihan yaitu area pembuangan sampah terutama yang mengarah pada rumah tinggal sementara (rumah pengasingan) Ir. Soekarno dan Drs. M. Hatta. Ketika dikonfirmasi kepada penjaga (juru kunci) sebagai penanggung jawab situs TKP, belum adanya tindak lanjut atas informasi dan harapan untuk membangun atau memperbaiki buangan sampah tersebut.

\section{Pembahasan Penelitian dan Rekomendasi}

Pembahasan hasil penelitian dan rekomendasi berkaitan dengan rumusan masalah dan studi terdahulu (penelitian terdahulu), bahawa:

1. Manfaat wisata TKP di Rengasdengklok Karawang, belum cukup besar karena belum adanya pembinaan dan dukungan terhadap usaha masyarakat sekitar oleh Pemerintah Daerah setempat. Ini bisa dilihat dari usaha dan hanya beberapa penduduk lokal yang mengambil peluang tersebut.

2. Peluang usaha masyarakat sekitar wisata TKP di Rengasdengklok Karawang untuk meningkatkan taraf hidup keluarga sebagai pedagang cukup menjanjikan karena wisata dapat memberikan kontribusi dari kedatangan pengunjung/wisatawan, dilihat dari rata-rata pendapatan setiap bulan masyarakat yang berdagang di sekitar wisata tersebut.

3. Manfaat wisata TKP di Rengasdengklok Karawang bagi masyarakat sekitar yang mengambil peluang usaha sebagai pedagang untuk meningkatkan taraf hidup keluarga sangat besar, karena berpeluang untuk mengembangkan sektor usaha yang lebih variatif yang dapat mengundang lebih banyak pengunjung/wisatawan. Jika dibangun sedemikian rupa seperti daerah wisata lain, kerajinan tangan tradisional ataupun produk tradisional Khas Karawang dapat ditawarkan karena jumlah wisata yang datang cukup menjanjikan dan tidak hanya dari dalam negeri saja. Informasi ini peneliti dapat dari penjaga situs wisata dan buku tamu yang disediakan bagi penginjung. 
4. Faktor-faktor yang menjadi kendala dalam menjalankan peluang usaha di wisata TKP di Rengasdengklok Karawang adalah tidak bervariasinya penawaran atas usaha masyarakat kepada wisatawan sehingga belum dapat menjadi nilai unggul dan kurang memberi efek manfaat yang lebih besar bagi peningkatan taraf hidup seluruh masyarakat sekitar. Peran serta pemerintah daerah belum terlihat sehingga belum dapat meningkatkan kompetensi atau keahlian masyarakat sekitar. Ditambah lagi, pengelolaan lingkungan atas sampah harus segera diperbaiki sehingga dapat memberi nyaman pengunjung. Jika pengunjung nyaman, dimungkinkan berlama-lama di tempat wisata tersebut dan menjadi peluang lebih besar bagi pedagang dan / usaha penduduk. Pengelolaan lingkungan termasuk sampah merupakan peran pemerintah daerah sebagai stakeholder untuk memahami keberadaan lingkungan yang sangat berpengaruh pada kenyamanan pengunjung. Pengelolaan lingkungan bisa dikerjakan oleh siapa saja, baik itu pihak pemerintah daerah, pihak swasta ataupun penduduk lokal yang mendapatkan kebijakan atas pengelolaan lingkungan.

\section{Hasil Pemetaan Konsep Dasar Penelitian}

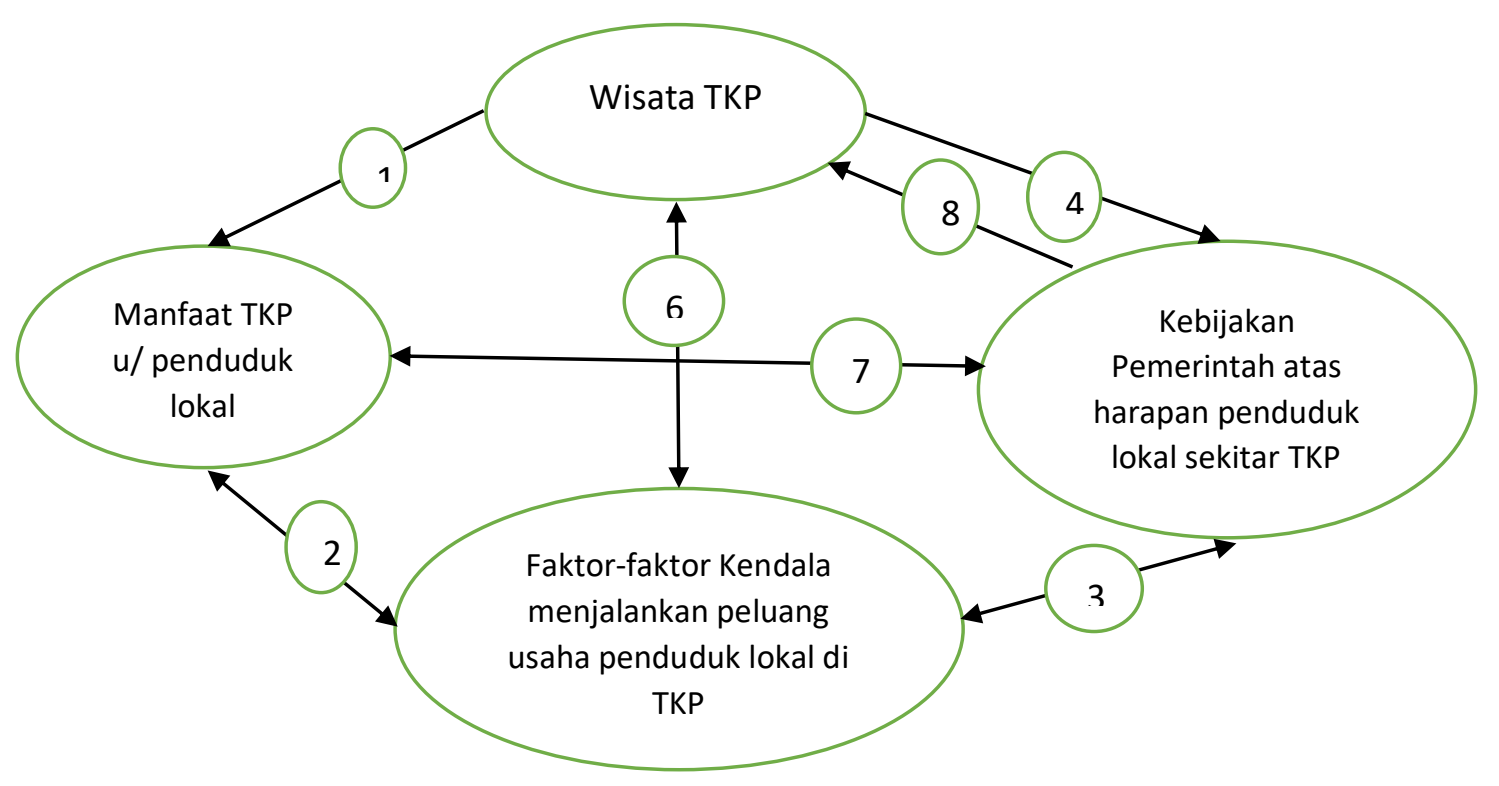

Gbr. 1.5 Hasil Pemetaaan Konsep Dasar

68. 
Dari hasil pemetaan, bias dijelaskan bahwa:

Pariwisata TKP memberikan nilai manfaat bagi penduduk lokal (1) sebagai peluang usaha, sedangkan manfaat yang diberikan oleh wisata TKP (6) bergantung pada faktor-faktor kendala (besar atau kecil), jika pengelolaan baik, akan meminimalisir kendala sehingga manfaat untuk peluang usaha dapat lebih dirasakan penduduk lokal (2). Wisata TKP bergantung dengan kebijakan pemerintah (4), dan kebijakan yang baik akan membantu wisata TKP menjadi lebih bernilai (8) dan bermanfaat (4)

Faktor-faktor kendala menjadi tanggung jawab pemerintah daerah (3) untuk dapat dikelola (dimanaj), jika kebijakan baik dan berkesinambungan (sustainable) serta sesuai dengan harapan penduduk lokal, maka wisata TKP akan jauh lebih bermanfaat bagi penduduk lokal (7) dan wisata TKP akan terus lebih baik, berjalan dan berkesinambungan dan terus menerus (continue).

\section{DAFTAR PUSTAKA}

Arslanturk, Yalcin at all. 2011. Time-verying linkages tourism receipts and economic growth in a small economic. Journal Economic Modelling.

Franz Schubert, Stefan at all. 2011. The impact of international tourism demand on economic growth of small economies dependent on tourism. Journal Tourism Management, 377-385.

J. Moleong, Lexy. 2014. Metodologi Penelitian Kualitatif. Remaja Rosda Karya. Bandung.

Pearce, Douglas. 1989. Tourist Development. Second edition.

Poudel, Surya at all. 2016. Stakeholders' Perspectives of Sustainable Tourism Development: A New Approach to Measuring Outcomes. Journal of Travel Research, Vol. 55(4) 465-480

Priono, Yasser.2011. Studi Dampak Pariwisata Bukit Batu Kabupaten Kasongan Ditinjau Dari Aspek Ekonomi, Sosial Dan Budaya. Jurnal Perspektif Arsitektur, Vol. 6/No. 2, Desember 2011.

Rahayu Agustin, Sri. Harian Pikiran Rakyat. Minggu (14/02/2016)

Sim, Rebecca. 2009. Food, place and authenticity: local food and the sustainable tourism experience. Journal of Sustainable Tourism, ISSN: 0966-9582 (print) 1747-7646 (online).

Sugiyono.2012. Metode Penelitian Kuantitatif, Kualitatif dan R\&D. Alfabeta. Bandung

Peraturan Menteri Dalam Negeri Republik Indonesia No. 41 Tahun 2012. Tentang Pedoman Penataan dan Pemberdayaan Pedagang Kaki Lima. www.kemendagri.go.id

69. 
Undang-Undang Republik Indonesia No. 20 Tahun 2008. Tentang Usaha Mikro, Kecil dan Menengah. www.ojk.go.id

Undang-undang Republik Indonesia No. 10 Tahun 2009 Tentang Kepariwisataan. www.kemenpar.go.id 